\title{
NEWYYSBKHOOL
}

digitalcommons.nyls.edu

Faculty Scholarship

Articles \& Chapters

$10-1-1994$

\section{National League of Cities: Judicial Decision- Making and the Nature of Constitutional Federalism}

Edward A. Purcell Jr.

New York Law School, edward.purcell@nyls.edu

Follow this and additional works at: http://digitalcommons.nyls.edu/fac_articles_chapters

\section{Recommended Citation}

91 Denver L. Rev.

This Article is brought to you for free and open access by the Faculty Scholarship at DigitalCommons@NYLS. It has been accepted for inclusion in Articles \& Chapters by an authorized administrator of DigitalCommons@NYLS. 


\title{
NATIONAL LEAGUE OF CITIES: JUDICIAL DECISION-MAKING AND THE NATURE OF CONSTITUTIONAL FEDERALISM
}

\author{
EDWARD A. PURCELL, JR. ${ }^{\dagger}$
}

I have profited greatly from reading Professor Sawyer's excellent articles on the Beveridge Child Labor Bill and the Court's classic decision in Hammer 1. Dagenhart, ${ }^{1}$ and it is no surprise that this article on National League of Cities (NLC) and the retum of constitutional federalism proves equally rich and rewarding. ${ }^{2}$ Like all good constitutional history, it deepens our understanding by showing the complicated nature of judicial decision-making and identifying the variety of factors that shape doctrinal change. ${ }^{3}$ His success in placing NLC in its historical context is especially valuable becalise the case has long seemed somewhat perplexing: surprising when it was announced, troubled in its subsequent applications, embarrassed by its relatively swift overruling, and at least partially vindicated by its resurrection only a decade later in altered form and under another name. Professor Sawyer's subject, however, is not the subsequent fate of $N L C$ but its historical origins and the lessons it offers for studies of judicial decision-making.

Given the immediate availability of his article, there is no need to summarize it in detail. Suffice it to say that it advances five principal historical claims: (1) that $N L C$ represented the "return" of constitutional federalism after a four-decade hiatus; (2) that it resulted from changes that occurred during the late 1960 s and early 1970 s in the structural operations of American government and the dominant assumptions of the nation's political discourse; (3) that changing attitudes toward the socalled "political safeguards of federalisn" (PSOF) were important in leading the Court to its decision; (4) that Justice Lewis Powell played a pivotal role in recognizing the flaws in PSOF and inducing the Court to act as it did; and (5) that, as a general matter, neither internalist nor externalist approaches to judicial decision-making, including dominant "political" interpretations, are adequate to explain NLC and the return of

$\dagger$ Joseph Solomon Distinguished Professor, New York Law School. The author thanks Michael McCarthy for his assistance in the preparation of this paper.

l. Logan Everett Sawyer III, Constitutional Principle. Partisan Calculation, and he Beveridge Child Labor Bill, 31 LAW \& HIST. Rev. 325 (2013); Logan Everet Saw yor III, Creating Hammer v. Dagcnhart, 21. WM. \& MARY BHL of RTS. J. 67 (2012).

2. Logan Everett Sawyer JI, The Rethrn of Constitutional Federalism, 91 DENV. U. L. REV. (forthcoming 2014 ).

3. "The mort we study events and situations in the past, the more complicated and complex we find them to be." GORDON S. WOOD, THE I'URPOSE OF THE PAST: REFLECTIONS ON THE USES OF HSTORY $10(2008)$. 
constitutional federalism. ${ }^{4}$ Neither the decision nor the return of constitutional federalism, Professor Sawyer maintains, can be explained "without considering the specialized language of doctrinal analysis and conceptual structures of constitutional theory that Justices use of justify their decisions." $"$

Professor Sawyer is surely right that neither internalist nor externalist approaches are adequate to explain judicial decision-making and that full historical explanations must account not only for both internal and external factors but also for the dynamic interactions between them. ${ }^{6} \mathrm{He}$ is also correct in emphasizing that the political and social developments of the 1960s and early 1970 s were pivotal in spurring the constitutional changes that began in the latter decade. ${ }^{7}$ More specifically, Professor Sawyer convinces me of three of his most original and insightful claims: (1) that contemporaneous political developments and resulting changes in attitudes toward PSOF played a special role in setting the stage for $N L C$; (2) that contemporary changes in the operations of the federal system took on particular doctrinal significance in Justice Powell's mind because he saw those changes as undermining the assumptions of PSOF; and (3) that Justice Powell's understanding of PSOF was an important factor in convincing him to support judicial intervention and thereby creating the Court's majority in $N L C{ }^{8}$

While Professor Sawyer's article is solidly researched, bighly illuminating, and persuasive in many ways, four qualifications seem in order. These involve his arguments concerning the "return" of constitutional federalism, the influence of "political" factors in NLC, the significance of Justice Powell's views concerning PSOF, and the role of doctrine generally in judicial decision-making.

\section{THE "RETURN" OF CONSTITUTIONAL FEDERALISM}

Professor Sawyer's framing claim that NLC marked a return to constitutional federalism is overbroad and possibly misleading, for it suggests, perhaps unintentionally, the unhelpful and ideologically-driven contention that the Constitution was forced into "exile" and "lost" as a result of the New Deal and subsequent twentieth-century developments. That contention is based on a misunderstanding of the nature and opera-

\footnotetext{
4. See Sawyer, supra note 2 .

5. Both NLC and the return of constitutional federalism "are best explained by considerines bow developments outside the Cotrt were fiftered through the conceptual structures of legal analysis." $/ d$.

6. I'rofessor Sawyer rejects stricty tegal explanations and emplasizes the dylamic role social forces play in shaping the course of the law, See $i d$.

7. See id.

8. See id.

9. Eg., RANDY E. BARNETT, RESTORING THE LOST CONSTHUTON: THE PRFSUMPTION OF LIBERTY (2004); ANDREW P. NAPOLITANO, THE CONSTITUTON IN EXILE: HOW THE FEDERAI. GOVERNMENT HAS SEIZED POWER BY REWRIING THE SLPREME LAW OFTHE I,AND (2006).
} 
tion of American constitutional government. ${ }^{10}$ While the federal system underwent significant transformations before and especially after the New Deal, World War II, and the Cold War, the structure of govemment that the Constitution established remained firmly in place and operated continuously throughout the decades before NLC. States and municipalities continued to act independently in many areas, electing their own officials, providing extensive services to their communities, and enforcing a wide range of diverse local policies. The political branches of the national government, moreover, though expanding their reach substantially, nonetheless continued to function as institutional checks on one another while also continuing to show solicitude for the states in a variety of areas. The Eisenhower administration sought to identify areas for future decentralization; the Senate protected state autonomy from the mandates of international human rights treaties; and Congress refused to extend the New Deal while cutting back on the national rights the New Deal had conferred on labor. " Most striking, until the mid-1960s Congress refused to intrude significantly into the racial practices of the states, and states' rights remained a politically powerful appeal. ${ }^{12}$ Constitutional federalism could not return, then, because it had never disappeared, and, though its operating system had evolved, its fundamental structure and underlying values had never stopped channeling the operations of American government. ${ }^{13}$

Professor Sawyer's article may, of course, intend the phrase "return of constitutional federalism" to refer to something much narrower, likely only to a judicially-enforced constitutional federalism. ${ }^{14}$ Even that more limited meaning, however, would still be somewhat overbroad. It is certainly true that the Court approved broad expansions of national power after 1937 and that it further extended that power in the 1950s and espe-

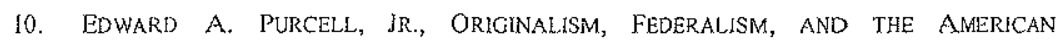
CONSTITUTIONAL ENTERPRISE: A HISTORICAL INQUIRY 193-94 (2007). Constitutional federalism in the United States is a complex governmental system shaped by innumerable cultural ass umptions, behavior patterns, and potitical institutions. Congress, the executive branch, and the federal bureaucracies logether with state and local governmental units and private institutions of all kinds determine to a very large extent how the system operates and evolves. The Supreme Court's role is critical, but it is also limited and in many areas only occasional or peripheral. E.g., WILLIAM N. ESKRIDGE, JR, AND JOHN FEREIOHN, A REPUBLIC OF STATUTES: THE NEW AMERICAN

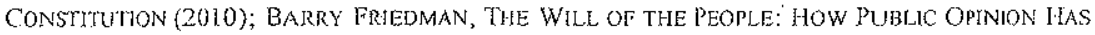
INFLUENCED the SUPREME COURT AND Shaped tHE MEANING OF the CONSTITUMON (2009); Jerry L. Mashaw, Creating the administrattve Constmution: The lost ONe Hundred YEARS OF AMERICAN ADMINISTRATIVE LAW (2012); Frederick Schauer, Foreward: The Comt's Agenda-chid the Nation 's, 120 HARV. L. REV. 4 (2006).

11. JAMES T. PATTERSON, GRAND EXPECTATIONS: THE UNTED STATES, 1945-1974, 50-52, 271-72 (1996); DUANe TANANBaUm, THE Bricker amendment CONTrOVERSY: A Test OF EISENHOWER'S POUTICAL LEADERSHEP (1988).

12. MiChAEL J. KLARMAN, FROM JiM CROW to Civil RIGHTS: THE SUPREME COURT AND THE STRUGGLE For RACIAL EQLALITY ch. 7 (2004).

13. SCe PURCELL. Supra note 10.

14. See Sawyer, stiprat note 2 . 
cially in the $1960 \mathrm{~s}^{15}$ However, it also remains true that during the same years the Court continued to supervise the operations of the federal system and limited various potential intrusions into state affairs. It expanded the power of the states to regulate economic activities, for example, and thereby provided judicial protection for new exercises of state lawmaking authority. ${ }^{16}$ Further, it continued to require federal courts to apply state common law rules when adjudicating state-created rights, limit the role of the independent federal common law, prevent broad uses of the civil rights removal statute, promulgate a variety of abstention doctrines designed to show deference to state judicial proceedings, and reject comprehensive incorporation of the Bill of Rights in favor of a more halting and partial approach. ${ }^{17}$ Finally, as Professor Sawyer's article notes, the doctrine of New York $v$. United States ${ }^{18}$ remained vital. ${ }^{19}$ Holding that "the sovereignty of the states required the Court to limit Congress's taxing power," the case stood as a clear example of an authoritative judicially enforced limit on national power. ${ }^{20}$ Thus, while $N L C$ surely represented a potentially major expansion of the judiciary's role in protecting the states, it was hardly unparalleled or unique in the Court's continuing efforts to honor that goal.

Professor Sawyer's claim about the return of constitutional federalism may also be misleading for another reason. It may suggest, again perhaps unintentionally, that the retum was to some true and possibly "original" normative constitutional understanding of federalism. No such historically true or correct understanding, however, exists. The federal system in its very nature is plastic, dynamic, and underdetermined, and its intrinsic structural characteristics have ensured that its operating system would evolve over the decades in response to compelling historical changes. ${ }^{21}$ Insofar as $N L C$ represented some kind of "return," it was only to what were predominantly late nineteenth- and early twentieth-century

15. Edward A. Purcell, Jr., The Courts, Federalism, and the Federal Constitulion, in 3 THE CAMBridge HISTORY OF LAW IN AMERICA: THE TWENTIETH CENTURY AND AFTER $(1920-), 141-$ 43, 154-56 (Michael Grossberg \& Christopher Tomlins eds., 2008).

16 E. . Stephen Gadbaum, New Deal Constitutionalism and the Unshaching of the Sittes, 64 U.CM. L. REV. 483, 550-52 (1997).

17. E.g., Betnhardt v. Polyeraphic Co. of America, Inc., 350 U.S. 198 (1956) (requiring application of state law over federal statute); Bank of America v. Pamell, 352 U.S. 29 (1956) (refusing to apply fexleral common law); Georgia v. Rachel, 384 U.S. 780 (1966) (construing civil rights removal statute narowly); Lousiana Power \& Light Co. v. City of Thibodaux, 360 U.S. 25 (1959) (approving federal court abstention in favor of state cout proceedings); PAUL L. MURPHX, THE CONSTIFUTION IN CRISIS TIMES, 1918-1969 377-84 (1972) (sketching the Court's increasing but still incremental activism in the 1960 s in developing the incorporation doctrine).

18. 326 U.S. 572 (1946). The Court did not reject the doctrine of the so-called (hild Labor Tax Case, Bailey r. Drexel Funiture Co., 259 U.S. 20 (1922), and throughout the period from the New Deal to NLC it held to Bailey's doctrine that Congress could not use its taxing pow to to impose "penalties" in order to regulate behavior in areas olherw ise beyond its constitutional authority. Barry Cushman, NFIB v. Sibelius and the Transfomation of the Taxing Poner, 89 NOtRE DAMEL. REV. $133,142-53(2013)$.

19. Sawyer, supra note 2 .

20. Id.

21. PURCELL, suma note 10. 
ideas about the Supreme Court's special role in protecting the states from congressional power. Those ideas did not represent the dominant view of the Founders, and they had begun to flourish only after the Civil War and Reconstruction. ${ }^{22}$ Thus, any attempted "return" was only to a position that had flourished between the end of Reconstruction and the New Deal, not to one that could claim the authority of a true and "original" constitutional understanding.

\section{JUDICIAL DECISION-MAKING AND THE NATURE OF" POLITICAL" INFLUENCE}

Professor Sawyer weakens his general argument challenging "simple" political explanations of $N L C$ by focusing on the significance of party affiliations and stressing the fact that four Justices took positions inconsistent with the position of the party that appointed them. ${ }^{23}$ Professor Sawyer first notes that Justices Black and Douglas (both of whom had left the Court before it decided $N L C$ ) were liberal Democratic appointees whose work in their later years on the bench anticipated the majority's position in $N L C{ }^{24}$ Second, he points out that Justices Brennan and Stevens were Republican appointees and that they dissented in the case. $^{25}$ Those facts, Professor Sawyer maintains, support the claim that NLC cannot be explained "sinzply" as a political decision. ${ }^{26}$

The argument is unpersuasive. Although party affiliation is often important and may sometimes be critical, ${ }^{27}$ it is the evolving social and political views, values, and assumptions of the Justices-their judicial ideologies, not their formal party affiliations - that are far more consistently relevant and determinative. ${ }^{28}$ The "Iines of cleavage on the court,"

22. Nineteenth-century ideas of federalism embraced stricter limitations on federal pow er, but prior to the Civil War it was largely the Senate and the states that were considered the primaty govenumental units responsible for maintaining those limits. Indeed, from the dratting of the Constitution to the Civil War and even beyond large numbers of Americans-especially those most conzmitted to protecting the rights of the states-saw the Supreme Court as a dangerous instrunent of encroaching national power: See, e.g., PURCELL, stipra note 10, at 140-52.

23. Sawyer, supra note 2 .

24. $l d$.

25. $l d$.

26. $l d$.

27. As l have argued it is, for example, in understanding much of the work of the current Court. Edwatrd A. Purcel1, Jr., From the Particular to the General: Three Federal Rules and the Jurisprudence of the Rehnquist and Roberts Courts, 162 U. PA. L. REV. (forthcoming 2014). The significance of party aftiliation varies from judge to judge, issue to issue, and time to time. Compare. e.g. Brian T. Fitzpatrick, An Enpirical Study of Class Action Settlemenis and Their Fee Awards. $7 \mathrm{~J}$. EMPURICAL LEGAL STUD. 811, 840-41 (2010) (stiting that Republican judicial appointees award sightly more attomeys' fees than Democratic appointees in class action settements), with Kevin $M$. Clemont \& Theodore Eisenberg, CAFA Judicala: A Tale of Waste and Politics, 156 U. PA. L. REV. $1553,1585-86(2008)$ (stating that Republican male judges in lower federal couts apply $C$ AFA with greater severity to restict class actions than do Democtatic judges or female Republican juciges).

28. In the context of jufficial decision-making, "political" does not mean that a judge is necessarily acting puposely and solely to achieve an immediate partisan or party-based goal. If means only, and more generally, that judges perceive both the facts of cases and the potentially applicable law through the Jens of their particular ideologies and that the social values and assumptions embedded in those ideologres help shape their assumptions, understandings, reasoning, and conclusions. 
Justice Louis Brandeis recognized almost a century ago, did not derive from party affiliation. ${ }^{29}$ Rather, he observed, they stemmed from the various Justices" "personal considerations" and even "prejudices," especially those involving labor, property, and "progressiveness." 30

Thus, what is truly critical in examining NLC and in exploring the extent to which it involved political considerations is the ideology of the individual Justices. ${ }^{31}$ For the two retired Democrats, the salient facts are that Justice Black lad grown increasingly conservative since the mid1960s and that Justice Douglas had long been an extreme individualist and judicial maverick. ${ }^{32}$ For the two Republican dissenters on the Court, the salient facts are that Justice Brennan was the Court's preeminent liberal nationalist and that Justice Stevens was a centrist and traditionalist who refused to abandon well-settled doctrine as the Court shifted to the right. ${ }^{33}$ Considering their judicial ideologies, the views of Justice Black and to a lesser extent Justice Douglas are quite understandable in political terms, while the dissents of both Justice Brennan and Justice Stevens are even more obviously understandable in those same terms.

Even worse for Professor Sawyer's use of party affiliation to challenge "simple" political explanations, the lineup of the other seven Justices in $N L C$ is not only understandable but strong evidence that $N L C$ was a highly and perhaps predominantly "political" decision. The majority Justices were all Republicans, with Justice Rehnquist writing for Chief Justice Burger and Justices Stewart, Blackmun, and Powell. The two

29. EDWARD A. PURCELL, JR, BRANDEIS AND THE PROGRESSIVE CONSTITUTION: ERIE, THE JUDICIAL POWER, AND THE POLITICS OF THE FEDERAL COURTS IN TWENTIETH CENTURY AMERICA $119(2000)$.

30. $l d$.

31. Studies of judicial decision-making have revealed many complexities, not just judicial ideologies with their social and political sources but also such other factors as strategic calcustation and personal interaction on multi-member courts. See, e.g., LEE EPSTEIN \& JACK KNIGHT, THE CHOICES JUSHCES MAKE (1997); Gregory A. Calueira, J. R. Wright, \& C.J.W. Zom, Sophisticated Yoting and Gate-Keeping in the Stipreme Court, 15 J. L. ECON. \& ORG. 549 (1999); Hatry T. Edwards, The Effects of Collegiality on Judicial Decision Making. 151 U. PA. L. REV. 1639 (2003); Lee Epstein \& Jack Knight, Toward a Strategic Rewolution in Judicial Politics: A Look Back, A Look Ahead, 53 Po1.. RES. Q. 625 (2000); Tinnothy R. Johnson, Janes F. Spriggs II. \& Paul J. Wahlbeck, Passing and Stralegic Voting on the U.S. Supreme Court, 39 L. \& SOC'Y REV. 349 (2005).

32. E.g., "Douglas's accomplishments on the Court were vast-and they were those of a brilliant, irascible individualist, not a team player." NOAH FELDMAN, SCORPIONS: THE BATTLES AND TRIUMPHS OF FDR's GREAT SUPREME COURT JUSTICES 432 (2010). As Professor Sawyer's article points out, for example, Justice Dotgglas had broken from his New Deal colleagues in 194.5 in New York v. United States when he cited the Tenth Anendment to argue for constitutional inimitations on the pow er of Congress to tax the states. Saw yer, supra note 2.

33. See gencrally JAMES F. SIMON, THE CENTER HOLdS: THE POWER STRUGGLE INSIDE THE REHNQUIST COURT (1995). See also THOMAS M. KeCK, THE MOST ACTIVIST SUPREMI: CoURt IN

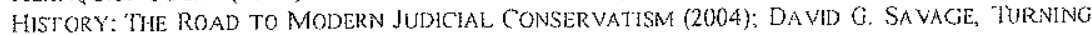
RigltT: THE MAKING OF THE REINQUIST SUPREME COURT (1993). For Stevens' views, see. e.g. Bell Atantic (Cop. y. Twombly, 550 U.S. 544,570, 578 (2007) (Sicvens, Ji, dissenting); Iolun Paul Stevens, The Court \& the Right to Fote: A Dissen, 60 The New York Review of Bonks 37 (A ugust $15,2013)$. 
dissenters who jomed Justices Brennan and Stevens, Justices White and Marshall, were both Democrats. ${ }^{34}$

Strikingly, the importance of judicial ideologies in $N L C$ was further confirmed nine years later when the Court overzuled the case in Garcia v. San Antonio Metropolitan Transit Authority. ${ }^{35}$ In another 5-4 decision that involved the same nine Justices, eight voted exactly as they had in NLC, while one, Justice Blackmun, switched sides. ${ }^{36}$ During the intervening nine years Justice Blackmun had moved from the Court's conservative wing to its liberal wing, and in Garcia he shifted his vote from the conservative to the liberal position. ${ }^{37}$

\section{JUSTICE POWELL AND PSOF}

Although Professor Sawyer's article sharpens our understanding of Justice Powell's views and highlights the key role he played in NLC, it does not probe deeply enough into the considerations that likely influenced his thinking. It argues persuasively that Justice Powell recognized the inadequacies of PSOF, the reigning constitutional theory that called for the Court to defer to Congress and the theory that $N L C$ rejected. ${ }^{38}$ On that foundation the article then implies that Justice Powell's position was consequently based on solid empirical evidence and sound theoretical critique and that it was not, therefore, simply political. ${ }^{39}$ Accepting the argument that Justice Powell's views in the case reflected his analysis of PSOF and that his thinking was thus not simply political, however, does not mean that the inferences he drew as to the legal significance of that analysis followed solely and automatically from either the empirical evidence or the theoretical critique. It does not mean, in other words, that

34. Professor Sawyer's article acknowledges this party lineup but terms it "insufficient" to make "political explanations" convincing "because concerns with limiting federal power emerged on the Supreme Cout before Nixon's four appointments anrived and were expressed by Justices [Black and Douglas] who cannot be characterized as supporters of Nixon, the New Right, or conservative politics more broadly." Sawyer, supra note 2 . This seens unconvincing. First, for the reasons suggested above, the invocation of Justices Black and Douglas provides little support for Professor Sawyer's thesis. Second, judicial ifeology explains the lineup of all the Justices who actually participated in $N L C$, and a narow party affiliation test accounts for the votes of seven of the nine Justices. These considerations suggest that-regardless of Justice Black and Douglas and even assuming that NLC was not "simply" political-it was nonetheless quite substantially political.

35. 469 U.S. $528(1985)$.

36. See id. (writing the opinion for the majority was Justice Blackmtun).

37. "When he retired in 1994, Justice Blackmun, a Nixon appointee, was the Court's most liberal member." SiMON, supra nole 33, at 307. For a persuasive explanation of Justice Black mun's lefward shif, see JOHN C. JEFFRIES, IR, JUSTICE LEWIS F. POWELL, JR.: A BIOGRAPIY 364-69 (2001).

38. Professor Sawyer's article stresses the importance of PSOF by declaring that it "had driven commerce clause jurisprudence for decades," had "for decades generated a consensus on the Cout that judicial deference to Congress on federalism gucstions was appropriate", and had won "nearly universal acceptance." Sawyer, stipra note 2.

39. Professor Sawyer's article similarly implies the decisive and apparenty nompolitical role of doctrinal factors when it states that Justice Powell"s contribution tay in "pushing the Court to conclude that doctrinal tensions" constituted "a sulficiunt justification" for its action in NLC. Jul. This suggests that the majority's animating goal was simply, or at feast primarily, lo resolve a doctrinal conflict. 
specific political considerations were absent from this thinking when he drew those inferences. ${ }^{40}$ The empirical and theoretical critique concerning PSOF was, after all, equally available to everyone on the Court, yet four of the eight remaining Justices disagreed with the legal conclusions that Justice Powell drew from it. ${ }^{41}$ Thus, something more than facts or theories seems to have been necessary to convince Justice Powell to draw the particular conclusions he did. ${ }^{42}$

Consider, then, two additional factors. First, though clearly a cautious and moderate judge, ${ }^{43}$ Justice Powell was also unquestionably a political and social conservative with deep, localist sentiments and strong ties to the business community. ${ }^{44}$ He was, for example, one of the original moving forces behind what became the "tort reform" movement that began to rally enthusiastic business support in the 1970s and quickly found a welcoming home in the Republican Party. ${ }^{45}$ Second, the statute that $N L C$ invalidated was not just any statute that affected state and local governments but a particular kind of statute, a muscular and heavily prolabor measure. Moreover, as the briefs challenging the statute argued, its enactment revealed not "the power of national interest groups" as a general matter but rather, and quite specifically, "the political power of labor unions." ${ }^{466}$ If, as Professor Sawyer maintains, the arguments in those briefs "convinced Justice Powell that NLC embodied his doubts about" PSOF, it is equally true that those same arguments carried obvious and heavy political weight. ${ }^{47}$ The briefs implicitly suggested that a statute that was so "ineffective", "unnecessary," and "undemocratic" 48 could only become law because of the determinedly and excessively prolabor

40. I should note that the Professor Sawyer's article offers mild criticism of my own work on matters related to $N L C$, though it also states that my political explanation is "more textured than a simple political explanation." Id.

41. See Nat'I League of Cities v. Usery, 426 U.S. 833 (1976).

42. Proiessor Sawyer's article acknowledges that legal materials were not, by thenselves, adequate to explain the Court's decision. Sawyer, supra note 2.

43. See, e.g., JefFries, supra note 30, at 369-70. City of Riverside v. Rivera, 477 U.S. 561 (1986), illustrates the point. There, Justice Brenan wrote for fou Justices advancing a generous interpretation of the Civil Rights Atforneys' Fees Statute, 42 U.S. C. 1988(b), and stressing its public purposes; while Justice Rehnquist wrote for four dissenters minimizing the statute's public purposes and urging a narow interpretation that would significantly reduce the awat at issue. Justice Pow ell cast the deciding vote, concuming in Justice Breman's result but questioning his rationale and relying solely on the district court's specific findings of facts.

44. See, e.g., JEFFrIES, supra note 30, at 188-93,296-98.

45. E.g., Memomandum, Attack on the American Free Enterprise System, from Lewis $\mathrm{F}$. Powell, ir. to Eugene B. Sydnor, Jr., Chaiman, U.S. Chanber of Commerce (Aug. 23, 197 1), araitable at hitp//Law.wlu.efu/deptimages/Powell\%20Archives/PowellMemorandum Typescript.pdi. See generaly. WILLIAM ILALTOM \& MICHAEL. MCCANN, DISTORTING THE LAW: POLITICS, MEDIA, AND THE lítigation Crisis (2004); JAY M. FEINMAN, Un-MAKING LAW: THE CONSTERVATIVE CAMPAIGN TO ROLL BACK THE COMMON LAW (2004).

46. See Sawyer, supra note 2.

47. Futther evidence of $N L C^{2}$ s political roots lies in the fact that, as professor Sawyer notes, in "justilying his vole" Justice Powell blamed the failure of PSOF on the fact that "the political muscle of organized tabor" oufweighed the power of "vintully every state and city in the nation arat what appeared to be overw helming local political views to the contrary. "Sce id.

48. See id. 
policies of the New Deal and the Democratic Party. ${ }^{40}$ Thus, whatever the exact nature of Justice Powell's reasoning, the specific arguments that supposedly confimed his doubts about PSOF were, in fact, arguments with striking political salience.

Indeed, consider another and perhaps even more important factor. PSOF was not simply an empirical theory purporting to explain the workings of the federal system or a nomative theory claiming an authoritative foundation in the Constitution's structure. It was also a highly effective political and ideological instrument undergirding mid-twentieth century liberal judicial nationalism. ${ }^{50}$ PSOF prescribed far more than the withdrawal of judicial protection from the states, for it also prescribed a clear judicial commitment to the protection of the constitutional values and interests that PSOF did not protect. Specifically, it identified the proper constitutional role of the federal courts as two-fold: the enforcement of national law, and the protection of the constitutional rights of individuals and minorities. In his classic essay elaborating PSOF, Herbert Wechsler based the first of those prescriptions-enforcing national law-on the theory's express logic. "The prime function for judicial teview-in relation to federalism-.," he wrote, "was the maintainance [sic] of national supremacy against nullification or usurpation by the individual states, the national government having no part in their composition or their councils." In a footnote he explained the related logic behind the second of those PSOF prescriptions:

The judicial function in relation to federalism thus differs markedly from that performed in the application of those constitutionat restraints on Congress or the states that are designed to safeguard individuals. In this latter area of the constitutional protection of the individual against the government, both federal and state, subordination of the Court to Congress would defeat the purpose of judicial mediation. For this is where the political processes cannot be relied upon to introduce their own correctives - except to the limited extent that

49. NLC addressed amendments to dhe Fair Labor Standards Act of 1938 (FLSA), 29 U.S.C. Sec. 201 et seq. (1940 ed.), the New Deal's last major piece of domestic legislation. Nat'] League of Citics v. Usery, 426 U.S. 833,835 (1976). The original FLSA had been upheld in the Court's landmark decision-fundamental to the so-called New Deal constitutional revolution-that overruled Hammer v. Dagenhart, 247 U.S. 251 (1918) and declared the Tenth Amendment a "truism" that did not linit congressional power. United States v. Darby, 312 U.S. 100, 116-17, 123-24 (1941).

50. PURCELL, sutpra note 10, at 157 . I have suggested elsewhere that the federal system often failed to work as the theory of PSOF proposed and that Hamilton and Madison, who adumbrated its argument in their defense of the Constitution and a stronger national government, may thenselves have had litte faith in it. $I d$. at $50-52,201-02$. Other earlier invocations of arguments paralleling the PSOF thesis had also been used to uphold national power over the states. Eg., Helvering v. Gerhardt, 304 U.S. 406, 412 (1938); MoCulloch v. Maryland, 17 U.S. 316, 435-36 (1819).

51. Herber Weclsicr, The Political Safeguards of Fecteralism. The Role of the Siates in the Composition and Selection of the natinal Govermment, 54 COLUM. L. REV. 543, 559 (1954) (emphasis adkled). 
individuals or small minorities may find a champion in some important faction. ${ }^{52}$

Not surprisingly, Wechsler immediately cited in support of that second prescription the other theoretical foundation of twentieth-century liberal constitutional jurisprudence, Justice Stone's famous footnote 4 in United States v. Carolene Products Co. ${ }^{53}$

In 1976, then, when Justice Powell considered the theory's significance, PSOF loomed as an animating theoretical justification for the Warten Court's liberal judicial nationalism-a theory that demonstrated that the true mission of the federal courts was to enforce national law and safeguard the constitutional rights of individuals and minorities. It was a theory, just like that of Carolene Products, that justified both the older liberalism of the New Deal and the newer liberalism that came with the Great Society and the high years of the Warren Court. ${ }^{54}$ Thus, in doubting PSOF, Justice Powell was doubting not some neutral or abstract theory of federalism but a vibrant constitutional justification for the prescriptions of contemporary liberalism and its commitment to a nationally oriented and highly "activist" and liberal federal judiciary.

Those considerations suggest a limitation to the thesis of Professor Sawyer's article. One can accept its argument that Justice Powell's doubts about PSOF were important in leading him to his conclusion in $N L C$ and that this shows that his actions were not "simply" political. That argument, however, does not show that his position was based entirely or even largely on "neutral" legal, empirical, or theoretical grounds. More important, it does not show that his position lacked compelling political inspiration and purpose.

Professor Sawyer's examination of Justice Powell's thinking is subtle and insightful, and it is surely right in declaring that a simple political explanation of $N L C$ misses important legal and conceptual considerations. ${ }^{55}$ In highlighting the role of such other factors, however, it seems to slight or elide the substantial political considerations that seemed clearly in play in the case, considerations that may well have been com-

52. Id. at $560 \mathrm{n} .59$ (cmphasis added).

53. Id; United States v. Carolene Products Co., 304 U.S. 144, 152 n.4 (1938).

54. Wechsler was himself an old New Dealer who wholeheartedly supported the New Deal's "constitutional revolution." Norman Silber \& Geoffrey Miller, foward "Neutra/ Princip/es" in the Lam: Selections from the Oral History of Herber Wechsler, 93 COLUM. L. REV. 854, 872-73 (1993). Subsequently, after his article on PSOF was published and the Court announced its decision in Brown v. Boud of Education, 347 U.S. 483 (1954), Wechsler developed serious doubts about some of the Court's actions in defending individual and minority rights, including Brown. Id. at 873-74, 924-28. Whatever Wechsler's later views on the Cout's role however, the liberal and activist implications that he made explicit in his PSOF cssay contimued to provide theoretical suppor for the Great Socicly, sec Sawyer, silpra note 2 as well as for the liberal nationalist jurisprutence of the Waryen Court.

55. See Sawyer, supra note 2 . 
pelling for at least some of the Justices-quite possibly even for Powell $^{56}$

\section{JUDICIAL DECISION-MAKING AND THE ROLE OF DOCTRINE}

Professor Sawyer's analysis of Justice Powell is intended to support a more general argument that legal doctrines (including, of course, principles, concepts, and rutes) matter and that they "play a role in generating constitutional change." ${ }^{57}$ On that, he is surely right. As a general matter, an entirely externalist approach would be profoundly simplistic, just as an entirely internalist approach would be.

That, however, does not carry analysis very far. In one sense, doctrines always matter. The norms and traditions of American legal discourse require that judges and commentators support their positions with proper constitutional sources and arguments. The problem, however, is that legal sources are often, though certainly not always, vague, elastic, indeterminate, or contradictory. Further, those advancing constitutional arguments can readily invoke or distinguish cases, infuse partisan meanings into texts, pick and choose among voluminous historical materials, shift levels of generality in construing principles and concepts, and employ ininumerable other techniques to deftly mold legal sources to fit their chosen ends. Thus, while doctrines always matter, they can matter in a nearly infinite variety of ways, from logically determinative control of an issue to strained justifications for unarticulated policy goals. ${ }^{58}$

The issue for legal historians, then, is not whether doctrines matter, but when, why, and how they matter. Thus, the issue they face is threefold: (1) at what point, on what issue, to what extent, and in what ways did they matter; (2) to the extent that they did matter, to what extent were they broadened, narrowed, or otherwise refitted to serve the conclusions and decisions reached; and (3) how is the particular role that they played (or failed to play) on any issue and in any given situation to be best un-

56. While Professor Sawyer's article clearty acknowledges the relevance of political considerations, it sometimes seems to downplay their general significance. It states, for example, that its "integrative explanation" involves an analysis of interactions between "the Court's unicule institutional norms" and "political change outside the Court." Id. Similarly, it states that NLC is "best explained by considering how developments outside the court were filtered through the conceptual structures of legal analysis." Id. These statements seen to suggest a narrower approach than one that examines the interactions between internal institutional and legal noms and both political developments outside the Court and the particular ideologies of the individual Justices inside the Court. Developments outside the Court, in other words, are filtered through both the specilic, ideologicallyshaped views and values of the individual Justices and "the conceptual structures of Iegal analysis."

57. See id.

58. E.g., the contrasting roles of established doctrine in limiting plantiffs' access to the federal courts in two recent class action decisions: Standard Firc lnsurance Co. v. Knontes, $133 \mathrm{~S}$. Ct. $134.5(2013)$ (unamimous decision reasoning convincingly from established doctrine); and Whl-Mant Stores. Inc. v. Dutes, 131 S. Ct. 2541 (2011) (5-4 decision reinterpreting estabtished doctrine to seriously restrict the use of class actions). 
derstood and explained. Doctrines do matter, but that conclusion answers none of the serjous and specific questions that legal historians ask."

\section{CONCLUSION}

In his article, Professor Sawyer accepted the challenge of asking and answering some of those serious and specific questions about the role of doctrines, principles, rules, and concepts. He has succeeded in showing that a specific set of changing historical conditions and growing doubts about a particular theory of federalism were at least contributing factors in leading Justice Powell, and perhaps other majority lustices, toward their decision in the case. Thus, he has expanded our understanding of $N L C$ and further illuminated the complex nature of judicial decision-making.

Professor Sawyer also wisely concludes with two additional and valuable points that should be noted. First, he cautions that federalism does not serve "inevitably" as a "tool to advance conservative values." As history amply shows, changing issues and contexts have shaped American interpretations of federalism, and advocates across the political spectrum have at one time or another sought to use it for their divergent purposes. It is no surprise, then, that amid the Court's contemporary federalism revival liberal writers have sought, as he points out, to turn its principles and values toward liberal ends. ${ }^{61}$ Second, Professor Sawyer wisely stresses the fact that many things began changing significantly in the years after $N L C$ with the election of Ronald Reagan and the vigorous growth of what he calls "the New Right." ${ }^{62}$ Thus, whatever the political roots of $N L C$, they are likely somewhat different from the political roots that subsequently generated the brand of judicially enforced federalism that began with the Rehnquist Court in the 1990s. Thus, in the policies and purposes behind their decision-making, there may be little similarity between the Court that decided $N L C$ and the Court that sought to initiate a broader "federalism revival" twenty years later.

59. Historians will, of con'se, often disagrce in answering those questions. In particular, they will disagree when, as professor Sawyer suggests, they attempt to determine which relevant factor, if any, was "the crucial cause." Saw yer, supra note 2.

60. $\quad$ ld.

61. The liberal interpretations of fexlemalism that Professor Saw yer points to are typical responses from those holding political views that $\mathrm{secm}$ nationally dislavored. $l d$. Conservatives of course, as he atso notes, sometimes want to exercise vigorous mitional powers. Id. See. e.g.. Purcell, supra note 15, at 163-64, 171-72.

62. See Sawyer, supra note 2 . 